Journal of Social Sciences (COES\&RJ-JSS)

ISSN (E): 2305-9249 ISSN (P): 2305-9494

Publisher: Centre of Excellence for Scientific \& Research Journalism, COES\&RJ LLC

Online Publication Date: $1^{\text {st }}$ October 2019

Online Issue: Volume 8, Number 4, October 2019

https://doi.org/10.25255/jss.2019.8.4.630.640

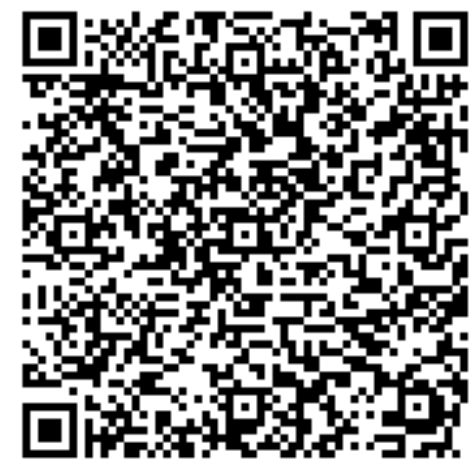

\title{
The Impact of Green Human Resource Management Practices (GHRMP) on the competitive advantage of the organization Muna Gharibeh
}

Yarmouk University -Master of Business Administration Email: munagh_1991@yahoo.com

\section{Abstract:}

The present study aims to investigate the impact of the green human resources management practices (GHRM) on the Jordanian educational organization competitive advantage. Furthermore, the study attempts to investigate the relationship between the GHRM and the competitive advantage of the organization; in terms of the Green selection and recruitment (S\&R), training and development (T\&D) and rewards system (RS) in the Jordanian educational organization. To achieve the study goals, I designed a questionnaire for data collection. However, the study community is the Jordanian organizations, and the study sample is the educational organizations in Jordan. The questionnaire is distributed to (9) educational organizations in Jordan within the period August to October 2018. The study found that the implementation of the green human resources management practices have a positive relation to increase the competitive advantage of the educational organizations in Jordan.

\section{Keywords:}

Green human resources practices, competitive advantage, Educational organizations.

\section{Citation:}

Gharibeh, Muna (2019); The Impact of Green Human Resource Management Practices (GHRMP) on the competitive advantage of the organization; Journal of Social Sciences (COES\&RJ-JSS), Vol.8, No.4, pp:630-640; https://doi.org/10.25255/jss.2019.8.4.630.640. 


\section{Introduction}

All over the globe, the environmental protection became one of the most important concerns in the last decades. However, preserving the natural resources to be used by the future generations is determined as the significant issue to be focused on by the policy makers and managers (Grenville et al., 2014). Therefore, the business organizations developed and adopt agree management by adopting the practices and procedures which friendly to the environment (Prasad, 2013). However, for achieving the new development, the organizations had created an official system of the environment management. (Chan, 2011) stated that the environment management system assured to be one of the most important methods in order to achieve the sustainable development. On the other hand, the human resource management is the most significant part in the firm; which can handle all of the activities together to achieve positive and maximum performance (Rawashdeh \& Al-Adwan, 2012). On the other hand, researchers suggested that HRM has a significant influence on the organization's development; therefore, scholars turned their attention to investigate the relationship and impact between HRM and the green practices. Scholars asserted that the green practices have a significant importance in the firm. Moreover, green human resources management refers to the alignment between the HRM and the environmental management (EM). This alignment aims to motivate the firms to improve the commitment of the employees towards the environment, in order to stimulate the environmental performance (Schuler \& Jackson, 2014.GHRM became an important issue to explore in Jordan. However, the researching this topic face some constraints; due to the few related to this topic. The current study aims to highlight the significant of GHRM and to investigate the impact of the GHRM practices on the competitive advantage of the organization in Jordanian educational sector.

\section{Statement of the problem}

Nowadays, the organizations are turning the concentration on the importance on adopting modern strategies; through integrating the sustainable environment among the HR strategies. Therefore, scholars focused on studying the applicability of the GHRM and its impact on the competitive advantage of the organization. However, the current study aims to analyze the terms, practices and constraints of the GHRM.

Moreover, the current study will shed the on helping the organization employees and assist them to adopt GHRM practices; in order to enhance their health and performance, and accordingly increase the competitive advantage of the organization. 
The Impact of Green Human Resource Management Practices (GHRMP)...

\section{Objective of the Study}

The study aims to explore the impact of the GHRM practices on the competitive advantage of the organization. Moreover, the objectives of the study can be summed up as following steps:

1. Identify the GHRM functions.

2. Identify the HRM functions.

3. Review the literature related to GHRM.

4. Identify the factors that affect the GHRM.

5. Identify the constraints that fact the implementation of the policies of the GHR.

6. Find the impact of the GHRM practices on the competitive advantage of the organization.

\section{Literature Review}

In their study, (Opatha; Arulrajah, 2014), they have defined the GHRM as the firm's policies, practices, and systems; that makes its workers green for the interest of people, business and nature. However, the GHRM includes different practices; selection and recruitment, training and development, compensation and rewards and performance. Hence, these practices are adapted in order to provide to enhance the green behavior of the employees (Mathapati, 2013).In their study, (Fayyazia et al., 2015) the researchers stated that there is a need for the EM in the HRM. However, (Rothenberg, 2003) stated that the successful EM inside the organization requires integrating the green practices in the human resource management. In their study, (Jabbour; Santos, 2008), the researchers declared that HR practices are required for achieving the effective environmental performance; in order to preserve the EM systems inside the organizations. Recently, many scholars have conducted researches to understand and identify the GHRM (Berrone \& Gomez-Mejia, 2009). However, GHRM practices are dependent on the ideal patterns of the green behaviors of the human resources managers (Muller Camen, 2011).Moreover, the study of (Haden et al., 2009) stated theta the integration of the environmental strategies E Samong the firm's strategic goals leads to achieving an effective EMS. Many researchers shed the lights on the HRM practices; because of its effectiveness in promoting the human capital, and enhancing the organizational performance and competitive advantage (Boselie, Paauwe, \& Jansen, 2001). Scholars assumed that GHR practices are very effective practices for enhancing the GH capital; because it can achieve the green competitive advantage. However, (Jose Chiappetta Jabbour, 2011) stated that the GHR practices are very effective and may guarantee including the green practices for the employees. Moreover, in Jordan, the implementation of the GHRM under research. Hence, the current study is based on three GHRM practices; selection and recruitment (S\&R), training and development (T\&D), and the green reward system (GRS). First of all, the most challenging issue for the HR manager is selecting and hiring the talented 
employees (Sudin, 2011). Selection and hiring green practices is sub-practice of the HRM practices. In these practices, the firm is provided with the opportunity to provide the initiatives of GHRM to the prospective applicants for a job. In their study, (Masri \& Jaroon, 2017) stated that business organizations are considering themselves to save the environment; in order to attract the smart professionals with green background and following the green practices. Furth more, job applicants reconsidering themselves as green employees and prefer the firms, which provide the protection for the environment and present the social responsibility. In their study, (Razabet al., 2015) suggested that interviewing the job applicants, the questions must include topics related to the environmental protection. On the other hand, the new joiners training must include providing information related to these policies and regulations of protecting the environment and the firms' green goals. However, the job interview should be prepared to estimate the qualification of the job applicants and comparing them with the green goals of the firm. Furthermore, one of the most important practices of the GHRM is the training and development; because it is required for applying the green management at firms. (Jose Chiappetta Jabbour, 2011) stated that one of the most important tools for enhancing the HR is the environmental training. However, the environmental training aims to enhance the employee's knowledge about the environment; leading to build the competence to decrease the waste and energy saving (Zoogah, 2011). Finally, the reward system has a vital effect for employee's motivation, and enhancing their performance (Teixeira et al., 2012). However, the purpose of adopting the rewards system is to motivate the employee's performance and to increase their attention for the importance of protecting the environment (Lindström \& Vanhala, 2011). Moreover, the (GRS) refers to the alignment of the green practices among the firm HR system. However, the GRS must be prepared to generate green initiatives within the workplace and lifestyle; in order to decrease the carbon effects (Pillai \& Sivathanu, 2014). Hence, the employees should receive rewards if they showed their interest commitment for environmental protection (Liebowitz, 2010).

\section{Hypothesis:}

H1. (GSR) have a positive impact on the competitive advantage of the organization in Jordanian educational organizations.

H2. (GT\&D) have a positive impact on the competitive advantage of the organization in Jordanian educational organizations.

H3. (GRS) have a positive impact on the competitive advantage of the organization in Jordanian educational organizations. 
The Impact of Green Human Resource Management Practices (GHRMP)...

\section{Methodology}

The current study aims at identifying the GHRM practices on the competitive advantage of the organization. However, the study is a qualitative research and explored the related literature of the GHRM. The researcher adopted data collection and data analysis approach. However, the researcher designed a questionnaire for data collection. HR department members were asked to fill the questionnaire; because they are assumed to have a good background about the GHRM practices, and their impact on the performance and the competitive advantage of the organization.

Total of (63) responses were collected from private and governmental educational organizations. Furthermore, data analysis performed by SPSS; through the descriptive statistical methods with mean, standard deviation, percentage, Pearson correlation coefficient, T-test and regression. Cronpach's Alpha was used to test the internal consistency of the instrument.

\section{Findings}

\section{Table 1}

\section{Table 2}

\begin{tabular}{|c|c|c|c|c|}
\hline & \multicolumn{3}{|c|}{ The Scale of the Relative Importance of the Mean } & \\
\hline & The Level of the Effect & \multicolumn{2}{|c|}{ The Mean } & \\
\hline & Low & \multicolumn{2}{|c|}{2.33 and less } & \\
\hline & Medium & \multicolumn{2}{|c|}{$2.34-3.67$} & \\
\hline & High & \multicolumn{2}{|c|}{$3.68-5$} & \\
\hline \multicolumn{2}{|l|}{ Category } & Mean & Std. Dev. & Level \\
\hline \multicolumn{2}{|c|}{ Green Selection and Recruitment (GS\&R) } & 3.02 & 1.15 & M \\
\hline \multicolumn{2}{|c|}{ Green Training and Development (GT\&D) } & 2.81 & 0.84 & M \\
\hline \multicolumn{2}{|c|}{ Green Rewards System (GRS) } & 2.86 & 0.92 & M \\
\hline \multicolumn{2}{|c|}{ Green Human Resources Practices } & 2.896 & 0.97 & M \\
\hline \multicolumn{2}{|c|}{ Decrease the Electricity Consuming } & 4.02 & 0.75 & $\mathrm{H}$ \\
\hline \multicolumn{2}{|c|}{$\begin{array}{l}\text { Increase using the renewable energy } \\
\text { resources }\end{array}$} & 3.61 & 0.86 & M \\
\hline \multicolumn{2}{|c|}{ Improve the organization reputation } & 3.94 & 0.71 & $\mathrm{H}$ \\
\hline \multicolumn{2}{|c|}{ Improve the organization services } & 3.88 & .72 & $\mathrm{H}$ \\
\hline \multicolumn{2}{|c|}{$\begin{array}{l}\text { Increase the competitive advantage of } \\
\text { the organization }\end{array}$} & 3.896 & 0.765 & $\mathrm{H}$ \\
\hline
\end{tabular}


Table 3

\begin{tabular}{|c|c|c|c|c|}
\hline & $S \& R$ & T\&D & RS & $\begin{array}{l}\text { The competitive } \\
\text { advantage of the } \\
\text { organization }\end{array}$ \\
\hline $\begin{array}{ll}\text { Selection } & \text { and } \\
\text { Recruitment } & \end{array}$ & 1 & 0.78 & 0.65 & 0.61 \\
\hline $\begin{array}{ll}\text { Training } & \text { and } \\
\text { Development } & \end{array}$ & & 1 & 0.72 & 0.53 \\
\hline Rewards & & & 1 & 0.58 \\
\hline $\begin{array}{l}\text { Increasing the } \\
\text { Organization } \\
\text { Competitive } \\
\text { Advantage }\end{array}$ & & & & 1 \\
\hline
\end{tabular}

Table 4

\begin{tabular}{|lr|l|l|l|}
\hline Variable & $\beta$ & T & Sig( t) \\
\hline $\begin{array}{l}\text { Selection } \\
\text { Recruitment }\end{array}$ & and & 0.328 & 4.12 & 0.001 \\
\hline $\begin{array}{l}\text { Training } \\
\text { Development }\end{array}$ & and & 0.336 & 3.90 & 0.000 \\
\hline Rewards & 0.350 & 3.94 & 0.002 \\
\hline
\end{tabular}

\section{Results}

According to data analysis, respondents agree upon adopting the GHRM practices. First of all, the application of the GHRM practices is (2.986) which is medium level. We found that the highest mean value is to the reduction of the consuming the electrical energy (4.02), then to improvement of the organization reputation (3.94). The third level belongs to the increasing the organization competitive advantage (3.986), then increasing the use of the renewable resources of energy (3.61). As well as, after that we found that selection and recruitment (mean $=3.02$ ), then the green reward system (mean $=2.86$ ) and the green training and development (Mean = 2.81). On the other hand, the third table shows that there was a positive correlation between the organization competitive advantage and the GHRM practices. However, the highest correlations related to the (GS\&R) practice (0.61). As well as, the lowest correlation is related to the (T\&D) (0.53). Moreover, the fourth table illustrates the multiple linear regression analysis results; that test the relationship of GHRM practices with the competitive advantage of the educational organizations in Jordan. 
The $(\alpha=0.742)$ indicates a high positive relationship with the competitive advantage. However, the $(F-v a l u e=89.05)$ shows that is a relationship with the competitive advantage, and the (value of the significance level $=0.000$ ) is related to $F$ value was less than 0.05 , suggested the relationship existence. The indicated results are consistence with other researchers (e.g. Paille et al., 2014; Renwick et al., 2013; Masri \& Jaroon, 2017; Ahmad, 2015; Mousumi \& Debabrata, 2016; Pavitra, 2017; Mandip, 2012).

\section{Discussion and conclusion}

The present study aims at investigating the impact of the GHRM practices on the competitive advantage of the educational organizations in Jordan. The studied GHRM practices are; selection and recruitment, training and developing and reward system. The researcher reviewed the related literature of each subdivision; in order to explore the potential green practices that might affect the competitive advantage of a specific organization. However, data collection was through reviewing the related literature and a designed questionnaire, which distributed to educational organizations in Jordan. The study found that the application of the GHRM practices have a positive relation with the competitive advantage of the organization; while the highest correlation was with the green selection and recruitment practice, and the lowest correlation related to the green training and development. However, this result is consistent to the study of (Marshal et al., 2014; Masri \& Jaroon, 2017). However the study found that the educational organizations do not develop the green training and development programs; because they are flowing the approach of reducing the cost. And since the educational organizations are the most important sector in any country; the Jordanian educational organizations are invited to increase the training and development programs budget; in order to enhance the implementation GHRM practices.

\section{References}

Ahmad, S. (2015). Green human resource management: Policies and practices. Cogent Business \& Management, 2(1), 1030817.

Arulrajah, A. A., Opatha, H. H. D. N. P., \& Nawaratne, N. N. J. (2015). Green human resource management practices: A review. Sri Lankan Journal of Human Resource Management, 5(1), 1-16.

Cherian, J. P., \& Jacob, J. (2012). A study of green HR practices and its effective implementation in the organization: A review. International Journal of Business and Management, 7(21), 25. 
Chan, E. S. (2011). Implementing environmental management systems in smalland medium-sized hotels: Obstacles. Journal of Hospitality \& Tourism Research, 35(1), 3-23.

Ghosh, S., \& Mukherjee, S. (2006). Measurement of corporate performance through Balanced Scorecard: an overview. Vidyasagar University Journal of Commerce, 11, 60-70.

Hair, J. F., Anderson, R. E., Tatham, R. L., \& Black, W. C. (1998). Multivariate Data Analysis, $5^{\text {th }}$ edPrentice-Hall. Englewood Cliffs, NJ.

Howard-Grenville, J., Buckle, S. J., Hoskins, B. J., \& George, G. (2014). Climate change and management, 57, 615-623.

Jose ChiappettaJabbour, C. (2011). How green are HRM practices, organizational culture, learning and teamwork? A Brazilian study. Industrial and Commercial Training, 43(2), 98-105.

Jabbour, C. J. C. (2013). Environmental training in organizations: From a literature review to a framework for future research. Resources, Conservation and Recycling, 74, 144-155.

Jabbour, C. J. C., \& de Sousa Jabbour, A. B. L. (2016). Green human resource management and green supply chain management: Linking two emerging agendas. Journal of Cleaner Production, 112, 1824-1833.

Jabbour, C. J. C., Santos, F. C. A., \& Nagano, M. S. (2010). Contributions of HRM throughout the stages of environmental management: methodological triangulation applied to companies in Brazil. The International Journal of Human Resource Management, 21(7), 1049-1089.

Jackson, S. E., \&Seo, J. (2010). The greening of strategic HRM scholarship. Organization Management Journal. 7(4), 278-290.

Jackson, S. E., Renwick, D. W., Jabbour, C. J., \& Muller-Camen, M. (2011). Stateof-the-art and future directions for green human resource management: Introduction to the special issue. German Journal of Human Resource Management, 25(2), 99-116.

Liebowitz, J. (2010). The role of HR in achieving a sustainability culture. Journal of sustainable development, 3(4), 50. 
Lindström, S., \&Vanhala, S. (2011). Divergence in HR functional roles in local government. Public Management Review, 13(7), 1023-1040.

Mandip, G. (2012). Green HRM: People management commitment to environmental sustainability. Research Journal of Recent Sciences, ISSN, 2277, 2502.

Marhatta, S., \&Adhikari, S. (2013). Green HRM and sustainability. International eJournal ofOngoing Research in Management \& IT. Retrieved from www.asmgroup.edu.in/incon/publication/incon13-hr-006pdf

Masri, H. A., \&Jaaron, A. A. (2017). Assessing green human resources management practices in Palestinian manufacturing context: An empirical study. Journal of cleaner production, 143, 474-489.

Mathapati, C. M. (2013). Green HRM: A strategic facet. Tactful Management Research Journal. 2(2),1-6.

Mishra, R. K., Sarkar, S., \&Kiranmai, J. (2014). Green HRM: innovative approach in Indian public enterprises. World Review of Science, Technology and Sustainable Development, 11(1), 26-42.

Mittal. V. K., \&Sangwan, K. S. (2014). Prioritizing drivers for green manufacturing: environmental. Social and economic perspectives. Procedia CIRP, 15, 135-140.

Roy, M., \&Khastagir, D. (2016). Exploring role of green management in enhancing organizational efficiency in petro-chemical industry in India. Journal of Cleaner Production, 121, 109-115.

Ones, D. S., \&Dilchert, S. (2012). Environmental sustainability at work: A call to action. Industrial and Organizational Psychology, 5(4), 444-466.

Opatha, H. \&Arulrajah, A. (2014). GHRM: Simplified General Reflection. International Business Research, 7(8), 101-113.

Mishra, P. (2017). Green human resource management: A framework for sustainable organizational development in an emerging economy. International Journal of Organizational Analysis, 25(5), 762-788.

Perron, G. M., Côté, R. P., \& Duffy, J. F. (2006). Improving environmental awareness training in business. Journal of Cleaner Production, 14(6-7), 551-562.

Pillai, R., \&Sivathanu, B. (2014). Green Human Resource Management. Zenith International Journal of Multidisciplinary Research, 4(1), 72-82. 
Paillé, P., Chen, Y., Boiral. O., \&Jin, J. (2014). The impact of human resource management on environmental performance: An employee-level study. Journal of Business Ethics, 121(3), 451-466.

Pinzone, M., Guerci, M., Lettieri, E., \& Redman, T. (2016). Progressing in the change journey towards sustainability in healthcare: the role of 'Green'HRM. Journal of Cleaner Production, 122, 201-211.

Ployhart, R. E. (2012). The psychology of competitive advantage: An adjacent possibility. Industrial and Organizational Psychology, 5(1), 62-81.

Prasad, R. S. (2013). Green HRM-partner in sustainable competitive growth. Journal of Management Sciences and Technology, 1(1), 15-18.

Prathima, M., \&Misra, S. (2012). The green revolution in human resource management. Asia Pacific Journal of Management \& Entrepreneurship Research, 1(3), 227.

Sathyapriya, J., Kanimozhi, R., \&Adhilakshmi, V. (2013). Green HRM-Delivering high performance systems. International Journal of Marketing and Human Resource Management, 4(2), 19-25.

Razab, M. F., Udin, Z. M., \& Osman, W. N. (2015). Understanding the role of GHRM towards environmental performance. Journal of Global Business and Social entrepreneurship (GBSE), 1(2), 118-125.

Rawashdeh, A., \& Al-Adwan, I. (2012). The impact of HRM practices on corporate performance in Jordanian commercial banks. African Journal of Business Management, 6(41), 10591-10595.

Rehman, M. A., \&Shrivastava, R. L. (2011). An approach to develop instrument for finding status of green manufacturing in India. Industrial Engineering Journal. 2(26), 24-30.

Renwick, D., Redman, T., \& Maguire, S. (2013). GHRM: A review and research agenda. International Journal of Management Review, 15, 1-14.

Sarkis, J., Gonzalez-Torre, P., \&Adenso-Diaz, B. (2010). Stakeholder pressure and the adoption of environmental practices: The mediating effect of training. Journal of Operations Management, 28(2), 163-176. 
SaturninoNeto, A., José ChiappettaJabbour, C., \& Beatriz Lopes de Sousa Jabbour, A. (2014). Green training supporting eco-innovation in three Brazilian companies: practices and levels of integration. Industrial and Commercial Training, 46(7), 387-392.

Schuler, R., \& E. Jackson, S. (2014). Human resource management and organizational effectiveness: yesterday and today. Journal of Organizational Effectiveness: People and Performance, 1(1), 35-55.

Sudin, S. (2011, June). Strategic green HRM: A proposed model that supports corporate environmental citizenship. In International Conference on Sociality and Economics Development, IPEDR (Vol. 10, pp. p79-83).

Teixeira, A. A., Jabbour, C. J. C., \& de Sousa Jabbour, A. B. L. (2012). Relationship between green management and environmental training in companies located in Brazil: A theoretical framework and case studies. International Journal of Production Economics, 140(1), 318-329.

Wherever, W. (2017). Greening people: Human Resources and Environmental Management.Routledge.

Wong, K. L., Tan, P. S. H., Ng, Y. K., \& Fong, C. Y. (2013). The role of HRM in enhancing organizational performance. Human Resource Management Research, 3(1), 11-15.

Wu, W. (2005). Business Research Methods. 2nded, Taiwan: Hwa Tai Publishing. Zoogah, D. B. (2011). The dynamics of Green HRM behaviors: A cognitive social information processing approach. German Journal of Human Resource Management, 25(2), 117-139. 